\title{
What can the UK learn from the Swedish pension reforms?
}

Received (in revised form): 17th August, 2005

\section{John Lawson}

is Marketing Technical Manager at Standard Life, Europe's largest mutual assurer. His role includes dealing with UK and European government on policy issues, both on behalf of Standard Life and as a representative of the UK insurance industry. $\mathrm{He}$ is a frequent commentator on pension issues in the UK trade and national press and writes widely for various UK trade publications. He is a member of the Association of British Insurer's European sub-committee.

\begin{abstract}
This paper discusses the advantages and disadvantages of the compulsory Swedish funded defined contribution (FDC) scheme, against the backdrop of the interest shown in this scheme by the UK Pensions Commission. It considers whether the benefits of the Swedish FDC put forward by its protagonists are real or illusory. It also considers the key lessons that the UK can learn from Sweden's experience.
\end{abstract}

Keywords: Sweden, pension, charges, Pensions Commission, Turner, Premium Pension Authority (PPM)

\section{INTRODUCTION}

In 2002, the UK Government set up a Pensions Commission under the stewardship of Adair Turner. Its remit is 'To keep under review the regime for UK private pensions and long-term savings $\ldots$ assessing the information needed to monitor progress and looking in particular at current and projected trends'.

On 12th October, 2004, the Pensions Commission published its first report 'Challenges and Choices'. 'This report is a comprehensive study of the UK pensions system and its ills. Steering clear of specific recommendations, the report issues a warning that people in the UK will have to work longer, save more, pay more taxes or retire poorer. Although specifically asked to consider only private pensions, the Pensions Commission strayed beyond its remit by addressing state pensions also. This was unavoidable given the intertwined nature of UK state and private pensions.
For those familiar with the 1990s Swedish pension reforms, the report contained numerous clues to the reader that Turner and the other commissioners favoured certain aspects of the Swedish system. Although not specifically mentioned in their report, the Swedish Financial Defined Contribution (FDC) system appears to have attracted the commissioners' particular interest.

Chapters 6 and 7 of the Pension Commission's report draw attention to and express concern about the level of charges in UK private pensions. This concern even extends to stakeholder pensions which have charges capped at 1.5 per cent for the first 10 years and 1 per cent thereafter. As the report observes, 'At this level, there is a real issue of whether personal pension saving by low earners is attractive'. The report attributes at least part of the reason for high charges to 'the very large costs created by lack of persistency and by contract proliferation'. 
In attempting to find solutions to these problems, it is perhaps understandable that the Pension Commission is looking closely at the Swedish model. After all, the Swedish FDC system maintains only one savings account for each individual compared with the five or six pension pots that a saver in the UK might accumulate over their working life. Speeches given by Adair Turner have provided concrete proof of the Pensions Commission's special interest in the Swedish FDC system, most recently his comments at an Investment Managers Association dinner in May 2005. ${ }^{2}$

\section{Swedish pension reforms in the $1990 \mathrm{~s}^{3}$}

Like many developed countries, Sweden's existing state pension schemes were becoming increasingly unaffordable due to changing demographics. The previous state pension system was a two-part universal flat-rate pension, originally introduced in 1946 and a supplementary earnings-related pension introduced in 1960. Both parts of this system were funded on a pay-as-you-go basis. The extent of the financial strain first became evident in the early 1980s.

Sweden appointed its own parliamentary pensions commission in 1984, which produced a comprehensive report, intended to serve as a basis for further debate. This report confirmed that maintenance of existing replacement rates would require an increase in contributions rates to levels that would become 'unbearable' for the working age population. The subsequent debate also focused on the inequalities of the benefit formula, which based benefits on the best 15 years earnings from a minimum of 30 qualifying years. This formula discriminated against those with a long working life and flat lifetime earnings; characteristics typical of those on low earnings.

In June 1998, the Swedish parliament approved a proposal for a new defined contribution state pension scheme. The new scheme is also a two-part system, based upon total contributions of 18.5 per cent of earnings. The first 16 per cent of contributions are credited to a notional defined contribution (NDC) account. The remaining 2.5 per cent goes into a funded (or financial) defined contribution (FDC) account. By making the whole system defined contribution, this means that all state pensions are earnings-related, although there is a defined benefit underpin to guard against an impoverished retirement.

The UK Pensions Commission is particularly interested in the funded tier.

\section{The Swedish FDC scheme ${ }^{4}$}

The FDC system establishes an individual privately managed funded account for each saver. A public agency, the Premium Pensions Authority (PPM) manages the system.

Each individual saver makes their investment choices from around 650 funds registered to operate in the PPM. Thus, there is a direct relationship between the size of each individual saver's fund at retirement, the return on the funds chosen by them and their lifetime earnings. Those who fail to choose their own funds have their contributions invested in the Premium Savings Fund (Premiesparfonden or AP7 fund), managed by the state fund, Sjunde AP Fonden.

The PPM is a clearinghouse for individual fund transactions. It also maintains individual accounts, provides daily information on participating funds, provides information to participants and is the monopoly annuity provider.

The Swedish National Tax Authority 
collects contributions. This authority was already responsible for collecting contributions under the old Swedish system and collects contributions for the NDC part of the new system. Utilising the existing contribution collection apparatus helps keep costs to a minimum. The tax authority charges back the PPM for its share of the cost of collecting contributions.

The Swedish National Debt Office holds new contributions in a block account for a period of around 18 months. The reason for this is that the exact value of contributions is not known until each saver's income is verified for that year. During this time, accounts earn a government bond rate of return.

An annual management charge applied to each saver's account covers fund management costs as well as the operational cost of the PPM. A condition for all fund managers participating in the PPM is that they must accept reduced charges when PPM funds under management in each fund reach pre-set thresholds. The PPM uses a system of rebates to apply this reduction. The fund management charge that the individual participant pays is the normal management charge for that fund (including the administration cost of the PPM) minus the rebate. No other explicit charges are allowed, although dealing and other costs (eg custody costs) incurred in the normal business of fund management are permitted.

Individual savers do not know what the fund management charge is in advance. The price paid by the saver depends on the weighted average of all individual choices. Therefore, savers must rely upon their fellow citizens to make similar fund choices to them if they are to enjoy the lowest possible charge.

In practice, the tendency of individual savers to make active fund choices is falling. As at December 2003, around two-thirds of PPM funds under management were invested in just 20 funds, with 30 per cent of funds under management invested in the default AP7 fund. ${ }^{5}$

The value of funds under management in the default fund as a percentage of total funds under management seems set to increase even further, as fewer savers are making an active fund choice when first joining the FDC scheme. When in 2000, 4.4 million savers were given their first opportunity to make a fund choice, 67 per cent of all participants did so $(70$ per cent by funds under management), with the remaining third, the non-choosers (30 per cent by funds under management), having their savings invested in the default fund. By 2004, the percentage of non-choosers had risen to 90 per cent, with only 10 per cent of savers making an active choice. ${ }^{6}$ The PPM uses funds accumulated by savers to buy an annuity at retirement age. The earliest age at which it is possible to draw a pension is 61 . The PPM, as the monopoly supplier, provides annuities, rather than savers having a choice of annuity supplier from the insurance market.

The PPM invests the decumulated funds of savers used to support annuities. The PPM presently chooses to invest these funds in government bonds generating an average real rate of return of only 2 per cent. This compares unfavourably with the average real rate of return of 5 per cent earned by savers on their financial accounts. ${ }^{7}$

\section{Setting up the PPM ${ }^{8}$}

In February 1998, the Swedish Government put out a call for tender for an account administration system for the future PPM. The bid was won by CSC Sverige AB (CSC), part of Computer 
Table 1: Total costs of administration of the PPM system

\begin{tabular}{|c|c|c|c|c|c|c|c|}
\hline & 2002 & 2005 & 2008 & 2011 & 2014 & 2017 & 2020 \\
\hline Total capital (billion kronor) & 78 & 152 & 260 & 400 & 574 & 781 & 1,011 \\
\hline Participants (thousands) & 5,466 & 5,815 & 6,167 & 6,504 & 6,793 & 7,033 & 7,237 \\
\hline Capital per participant (kronor) & 14,293 & 26,129 & 42,233 & 61,475 & 84,477 & 111,121 & 139,660 \\
\hline PPM charge (\%) & 0.30 & 0.23 & 0.18 & 0.15 & 0.12 & 0.08 & 0.04 \\
\hline Average fund charge (\%) & 0.41 & 0.36 & 0.32 & 0.29 & 0.27 & 0.25 & 0.24 \\
\hline Total average charge (\%) & 0.71 & 0.59 & 0.50 & 0.44 & 0.39 & 0.33 & 0.28 \\
\hline
\end{tabular}

Sciences Corporation which is one of the world's largest IT companies. Following delays in the project and having very carefully considered several different options, the PPM decided to continue the cooperation with CSC. However, due to the change in the delivery date, the Swedish Government asked the PPM to draft a reserve plan, in case further delays arose in the development of the account administrative system.

In late 1999, the PPM decided to develop an in-house system. During the following months, development of the in-house and the CSC systems continued in parallel. The development of the in-house system went very well, so much so that the PPM chose to continue developing the in-house system and to cancel the agreement with CSC.

According to the agreement, the PPM had to pay compensation to CSC because of the cancellation. At that point, the PPM had paid just over SEK $54 \mathrm{~m}$ to CSC. No agreement was reached on the size of the compensation owed by the PPM, and in January 2001, the dispute was referred to an arbitration board. The arbiters ordered the PPM to pay CSC SEK116m, plus interest and legal costs. The total amount was SEK157.2m. ${ }^{9}$

This means that the PPM incurred costs of over SEK $200 \mathrm{~m}$ ( $€ 21.4 \mathrm{~m}$, $\left.\mathcal{E}^{14.6 \mathrm{~m}}\right)^{10}$ for an IT system it never used.

\section{Administration costs of the PPM}

One of the main features of the Swedish FDC that has attracted the UK Pensions Commission's interest is the low administration expenses relative to most of the other new state defined contribution systems that have been established over the last 25 years or so (eg Australia, Chile). Table 1 is an extract from 'Sweden's New FDC Pension System', ${ }^{11}$ a paper by Edward Palmer, Professor of Social Insurance at Uppsala University and Head of the Research Division at the Swedish National Social Insurance Board. Palmer bases these figures on data supplied by the actuarial division of the PPM and his own calculations.

These figures do not cover the cost of collecting contributions. From 2005, the PPM will pay for its proportionate share of contribution collection. Palmer estimates that this will increase the total average charge to 0.62 per cent (from 0.59 per cent) in 2005 and to 0.29 per cent (from 0.28 per cent) in 2020 .

\section{Fund management choices and charges}

As noted, savers can choose from a range of around 650 funds. The amount of PPM savers' money invested in these funds varies enormously from only SEK5,243 ${ }^{12}(€ 561, \ldots 382)$ in the Banque de Luxembourg Global Equities fund up to the non-chooser fund, the AP7 fund, which invests over SEK40bn ${ }^{13}(€ 4.3 \mathrm{bn}$, 
Table 2: How the AP7 was invested as at 31st December, 2004

\begin{tabular}{lcc}
\hline & Amount invested (SEK) & Percentage of overall fund (\%) \\
\hline Equity related securities & $33,179,947,000$ & 82.7 \\
Unlisted equity-related securities & $1,596,923$ & 4.0 \\
Fixed-income securities & $4,213,677$ & 10.5 \\
Equity-based derivatives (net) & 100 & 0.0 \\
Currency derivatives (net) & $1,170,443$ & 2.9 \\
& $40,161,090,000$ & 100.1 \\
\hline
\end{tabular}

£2.9bn) of PPM savings. More than 330 funds manage less than SEK10m ${ }^{14}$ $\left(€ 1.07 \mathrm{~m}, \text { f }^{0.73 \mathrm{~m})}\right)^{15}$

The fund with the lowest charge is the AP7. The gross charge for this fund is 0.5 per cent, but after applying the rebate, this falls to 0.15 per cent. ${ }^{16}$

The highest charge fund within the top 20 is HQ Rysslandsfond with a gross charge of 2.5 per cent, falling to 0.73 per cent after the rebate is applied. ${ }^{17}$

Table 2 shows how the AP7 was invested as at 31 st December, 2004. ${ }^{18}$

Although the individual saver pays only 0.15 per cent (2004) for funds invested in the Premiesparfonden, this level of charge is not sufficient to cover the costs of the fund manager (Sjunde AP-Fonden, 7th AP Fund). Recent discussions between the Swedish Ministry of Finance and the AP fund mangers have focused on the need for the AP funds to cut their annual costs. ${ }^{19}$

In 2004, expenditure of AP7 exceeded income (after rebates) by SEK17.6 $\mathrm{m}^{20}$ $\left(€ 1.89 \mathrm{~m}, \mathcal{f}^{1.28 \mathrm{~m})}\right.$. Since establishment of the AP7 in 2000, cumulative losses total SEK155m ${ }^{21}(€ 16.6 \mathrm{~m}, £ 11.3 \mathrm{~m}) .^{22}$

This means that the operation of this fund manager is effectively being subsidised by the Swedish taxpayer (largely through loans from the Swedish National Debt Office).

In 2004, the actual charge applied to accounts invested in the AP7 fund was 0.15 per cent. ${ }^{23}$ If management costs of the AP7 were fully covered, this charge would need to rise to 0.193 per cent.
The charge would need to be higher still to allow the AP7 to clear its accumulated losses.

\section{Comparing charges in Sweden and the UK}

As noted earlier, a key feature that has attracted the interest of the UK Pensions Commission to the Swedish FDC system is its low costs.

However, Swedish charges do not always fully reflect the true cost of doing business. As noted above, the AP7 currently runs at a loss.

The 30 basis points cap on the cost of PPM administration is also insufficient to cover the running costs of the PPM. The 'Swedish Pension System Annual Report 2003' states the costs of administration as SEK $351 \mathrm{~m},{ }^{24}$ whereas the 30 basis point charge deducted from funds only raises revenue of SEK $242 \mathrm{~m} .{ }^{25}$ The Swedish National Debt Office finances the balance with interest-bearing loans. The expectation is that as funds under administration grow, the need for debt finance to subsidise administration costs will disappear. The administration charge deduction will not truly reflect the running costs of the PPM until these loans are repaid (expectation is in $2018^{26}$ ).

This means that the true cost of running the PPM as a percentage of assets under administration in 2003 was not 30 basis points. The true charge was in fact 43.5 basis points $(351 / 242 \times 0.3)$. 
Table 3: Comparison of charges in Sweden and the UK

\begin{tabular}{llll}
\hline & $\begin{array}{l}\text { UK employer- } \\
\text { sponsored stakeholder } \\
\text { and UK group } \\
\text { personal pension }\end{array}$ & $\begin{array}{l}\text { Sweden actual } \\
\text { Charge component }\end{array}$ & $\begin{array}{l}\text { Sweden true } \\
\text { charges based on } \\
\text { actual underlying } \\
\text { costs }\end{array}$ \\
\hline $\begin{array}{l}\text { Administration, manufacture, } \\
\text { marketing, profit margin }\end{array}$ & $0.1-0.3$ & 0.3 & $0.465^{\star \star}$ \\
$\begin{array}{l}\text { Fund management } \\
\text { Distribution/advice }\end{array}$ & $0.1-1.0$ & $0.15-0.73^{\star}$ & $0.193^{\star \star \star}-0.73$ \\
$\begin{array}{l}\text { Return on capital } \\
\text { Total annual management charge (\%) }\end{array}$ & $0.1-0.7$ & 0 & 0 \\
$\begin{array}{l}\text { Total annual management charge } \\
\text { excluding charge to cover }\end{array}$ & $0.1-2.1$ & 0 & 0 \\
distribution costs (\%) & 0.4 & $0.45-1.03$ & $0.658-1.195$ \\
\hline
\end{tabular}

${ }^{*}$ Range of fund management charges applicable to the 20 largest funds, lowest is actual charge for AP7 fund ${ }^{*}$ Includes the three basis points cost estimated by Palmer (2004) that will be incurred from 2005 when the PPM starts to pay for its share of the cost of collecting contributions

${ }^{* \star}$ True unsubsidised annual management charge of AP7 fund if the full costs of fund management were expressed as an annual management charge (see section on 'Fund management choices and charges' above)

This lack of transparency makes it difficult to compare the Swedish FDC with the UK private pension system on a like-for-like basis. The commercial organisations that operate the UK private pension system cannot afford to run their businesses at a loss indefinitely. Nor would UK private pension providers consider borrowing funds to subsidise administration charges paid by savers. The charges levied by UK pension providers are therefore a fairer reflection of the underlying expenses and profit margin.

Another issue that makes comparison difficult is the stability of the pension system. It is clearly the expectation that the changes put in place by the Swedish government in the 1990s will last a long time (at least 20 years). This means that the PPM does not need to make any major changes to its IT capabilities or administration processes in the near future.

UK private pensions have not enjoyed the same stable environment. Over the last 20 years, there have been numerous major changes to pensions and tax laws. ${ }^{27}$ Each of these changes has resulted in private pension providers incurring substantial IT and administration process costs. The additional costs incurred are reflected in the level of charges payable by retirement savers.

Table 3 presents a comparison of charges paid by savers in the Swedish FDC system and UK group personal pensions and UK group stakeholder pensions.

Despite the almost constant changes in UK pensions and tax law, and the cost to private pension providers of dealing with these, the charges levied by UK private pension providers compare surprisingly well against Swedish FDC charges. Leaving aside the cost of advice, the lowest charge UK stakeholders and group personal pension schemes currently operate at charges up to 50 per cent lower than the subsidised Swedish FDC charges, and at less than half of the unsubsidised Swedish charge.

The expectation is that Swedish FDC charges will fall substantially in the longer-term to around 30 basis points (see 'Total costs of administration of the PPM system' above). ${ }^{28}$

However, although the expectation is that FDC charges will fall, this might not happen for two reasons: 
1 The costs of administration might be higher in future than expected. This could happen if, for example, the Swedish government legislates for any significant changes that require the PPM to execute expensive IT and process changes.

2 Fund managers increase their fees. There is a significant temptation for fund managers to increase fees and profit margins, having already attracted a large number of savers. In fact, some managers participating in the PPM may have artificially pitched their fees at an unprofitable level with the sole aim of attracting savers. There is already evidence that this has happened, Skandinaviska Enskilda Banken having increased its fees in 2004 from 0.5 per cent to 1.2 per cent for 71,000 FDC savers on its loss-making generation funds. ${ }^{29}$

On the other hand, there is also potential for UK private pension charges to fall substantially over the same period. To some extent, this will depend upon whether UK politicians can avoid making further changes to tax and pensions law.

UK charges depend on a range of factors. For example, the fund in which savings are invested (Sweden has a similar difference), the number of scheme members (not applicable in the Swedish FDC) and the average level of contributions (all members pay the same charge to the Swedish FDC regardless of contribution level).

The key differentiator between the Swedish FDC and UK private pensions is that the latter sometimes incorporates a charge for advice. This is not normally the case where the intermediary advising the employer is an employee benefits consultancy (EBC). EBCs normally charge employers a fee for advice on the most appropriate type of pension scheme, but do not normally give individual employees advice. In this distribution model, total annual management charges exclude any distribution cost element, and for most employees, fall in the $0.3-0.7$ per cent range (the exception being those employees who choose the highest charging funds).

The advice model for advisers other than EBCs is different. Here, advisers are paid commission for advising both the employer and employees. Advice to employees may either be one-to-one or via group presentations. Charges in this distribution model are higher, falling in the $1.0-1.5$ per cent range for most employees.

\section{Swedish problems that the UK should not copy}

Although relatively new, the Swedish FDC system is not without problems. The low number of new joiners making active fund choices is one such issue. Another is the role of the PPM in investing annuity-backing funds and the rate of return achieved on these funds. The Swedes have already recognised these problems and they are currently the subject of debate.

\section{The high number of non-choosers}

As noted earlier, the number of non-choosers among new FDC entrants has risen from 33 per cent in 2000 to 90 per cent in 2004. ${ }^{30}$ However, this apparently worrying trend among new entrants to the FDC is perhaps not as threatening as it first appears.

Those making a fund choice when the FDC first allowed in 2000, represented the whole working population: the whole range of ages and incomes. Because the FDC system was originally set up in 1995, there was already 
approximately four years' worth of contributions awaiting investment for the majority of savers making an investment choice in 2000. The reasons for this build-up of funds was that final details of the FDC system had not been determined in 1995, and the administration platform (the PPM) was not capable of allocating accumulated savings to the chosen fund manager until 2000 (due to the previously mentioned IT problems).

Those having a large lump sum to invest are more likely to have an interest in where those savings are invested.

In contrast, new entrants to the FDC system in 2004 are mainly young people in their first jobs. Low earnings mean that the contributions paid to the FDC system are relatively small in nominal terms. Therefore, there is likely to be little interest in allocating these contributions to specific funds.

If the new FDC system is to operate as intended, engagement with the saving population, particularly among young workers, needs to improve.

When advice is included within the UK charge, the Swedish system does have lower charges. Experience of group stakeholder pension schemes administered by Standard Life, however, shows that two-thirds of members make an active fund choice. ${ }^{31}$ Even though the cap on stakeholder charges (1 per cent from 6th April, 2001 to 5th April, 2005) limits the scope of advice that can be given, this does provide some evidence that advice results in a greater number of savers making active fund choices.

\section{Excessive concentration of savers using the AP7 fund}

Although the number of new entrants investing in the default AP7 fund is 90 per cent, the AP7 still only manages around 30 per cent of the total FDC funds under management. However, if the new, non-chooser, entrants fail to move their funds out of the AP7 as their earnings increase in the future, then the percentage of savings invested in the AP7 will rise.

The AP7 is just one single fund trying to meet the diverse needs of the whole Swedish working population. As such, it cannot reflect the risk attitudes of each individual. Nor can it ensure that savers approaching retirement take a more prudent investment approach. As noted, ${ }^{32}$ the AP7 fund has a near 83 per cent equity weighting. While this investment strategy may suit the majority of those with a ten-year plus investment horizon (mainly younger workers), it introduces an avoidable risk for those approaching retirement. For example, had the FDC been a mature system in March 2003, those retiring in that month, and fully invested in the AP7 fund, would have seen their actual pension fall substantially from that expected less than three years earlier, towards the end of 2000. This is because some world equities markets lost 40 per cent or more of their capital value over this period. ${ }^{33}$

Should such a situation arise in future, it would almost certainly damage the confidence of Swedish workers in the FDC system. It is likely that the Swedish government would also come under scrutiny for failing to have foreseen such an outcome.

In the UK, the stakeholder default 'lifestyle' funds, managed by each pension provider, are predominantly invested in equities but gradually switch retirement savers into cash and bonds, most commonly during the 10 years immediately preceding retirement. This investment strategy ensures that the variance between the actual pension received at retirement measured against the pension expected by the saver in 
the years preceding retirement is minimal.

\section{The complexity of the rebate system}

The rebate system is excessively complex and lacks transparency. The cooperation agreement between fund managers and the PPM sets out details of how the rebate is calculated. ${ }^{34}$ The method of rebate calculation is beyond the understanding of most, except perhaps those with an advanced knowledge of mathematics. In addition, as previously noted, the actual level of charges is not known in advance, depending upon the weighted average of choices made by FDC savers.

\section{What can the UK learn from Sweden?}

The UK already has a significant private pension administration capability. As shown earlier, UK administrators can offer pension accounts to savers at competitive charge levels, with some schemes in the UK currently operating at charge levels below even the lowest (subsidised) charges in the Swedish FDC.

However, one reason why this competitive advantage may disappear in future is the proliferation of accounts in the UK. When UK savers move jobs, they are unlikely to transfer their accumulated retirement savings fund to their new employer. This means that savers accumulate several savings accounts over a working life.

Savers can also end up with more than one savings account in respect of the same period of employment with the same employer. This can happen when an adviser persuades the employer to terminate their current pension scheme and open up a new one. There could be several reasons why an adviser may recommend this course of action, but the two most common reasons are:
- because legislative change makes a different type of scheme more desirable; and

- to provide a new scheme that offers employees greater flexibility and more options than the old one.

Savings accumulated in previous pension schemes of current and former employers are transferable, but the process is difficult. Therefore, few savers attempt to consolidate their funds.

Borrowing the idea of the clearinghouse model from Sweden would solve the problems of persistency and account proliferation in the UK. From the employee's point of view, this would work on a similar principle to current bank accounts. The employee would simply supply their new employer with their pension account details. The employer would then direct contributions to the employee's chosen account via a clearinghouse. From the employer's point of view, the clearinghouse would be needed to avoid establishing payment links with the chosen pension provider of each employee.

\section{Conclusion}

Sweden has come up with an innovative model that fits well with its own needs and history. There are some clear lessons that the UK can learn from studying the FDC system.

Nevertheless, copying the Swedish FDC system in its entirety would be a mistake for the UK. UK private pension administration is already an efficient business. Centralising and nationalising the UK pensions administration system is, therefore, unnecessary. However, the UK private pension system could operate more efficiently in the longer-term if it can solve the problems of poor persistency and account proliferation. One solution that the UK Pensions 


\section{Commission should consider is the clearinghouse model.}

\section{References}

1 Turner, A., Drake, J., and Hills, J. (2004) 'Pensions: Challenges and Choices. The First Report of the Pensions Commission', available at:

www.pensionscommission.org.uk.

2 The full text of Turner's speech is available at: http://www.pensionscommission.org.uk/ publications/2005/IMA250505.doc.

3 For more information see eg Palme, J. (2003) 'Pension reform in Sweden and the changing boundaries between public and private' in G. Clarke and N. Whiteside (eds) 'Pensions Security in the 21st Century', Oxford University Press, Oxford.

4 Palmer, E. (2004) 'Sweden's New FDC Pension System', Premium Pension Authority, available at: www.ppm.nu.

5 Source: Premium Pensions Authority (PPM), Statistics and current issues, www.ppm.nu/dbfiles/xls/2162

6 Ibid.

7 Palmer (2004), op. cit.

8 PPM, www.ppm.nu/dbfiles/pdf/2164.pdf

9 Swedish Pension System (2002) 'Costs of administration', p. 23; note 19. Swedish Pension System Annual Report 2002.

10 Exchange rates correct at 17th August 2005.

11 Palmer (2004), op. cit.

12 PPM, op. cit, ref. 5.

13 Ibid.

14 Ibid.

15 Exchange rates correct at 17th August 2005.

16 Sjunde AP-Fonden (2004) 'Annual Report 2004'. Available at: www.ap7.se.

17 PPM, op. cit, ref. 5.

18 Sjunde AP-Fonden (2004), op. cit.

19 RC (2005) 'Swedish government takes AP funds to task over costs', European Pensions and Investment
News, 6th June.

20 Sjunde AP-Fonden (2004), op. cit.

21 Ibid.

22 Exchange rates correct at 17th August 2005.

23 Sjunde AP-Fonden (2004), op. cit.

24 Swedish Pension System (2003) 'Premium pension, income statement and balance sheet', p. 11; 'Costs of administration', p. 24, note 17. Swedish Pension System Annual Report 2003.

25 Swedish Pension System (2003) 'Deduction for costs of administration' p. 25, note 24. Swedish Pension System Annual Report 2003.

26 Ibid.

27 Examples of major legislative changes: Finance (No.2) Act 1987, Pensions Act 1995, Finance Act 2000, Stakeholder Pension Schemes Regulations 2000, Finance Act 2004, Pensions Act 2004.

28 Palmer (2004), op. cit.

29 Weaver, R. K. (2003) 'Design and Implementation Issues in Swedish Individual Pension Accounts', Social Security Bulletin, Vol. 65, No. 4; Available at: http://www.ssa.gov/policy/docs/ssb/v65n4/ v65n4p38.html.

30 PPM, op. cit, ref. 5.

31 Standard Life (2005) Own data (group stakeholder schemes) for period 6th April 2001 to 5th April 2005 inclusive.

32 Sjunde AP-Fonden (2004), op. cit.

33 For example, the capital value of the FTSE 100 index fell by over 47 per cent between 29th December 2000 (index close 6,222) and 12th March 2003 (index close 3,287). The capital value of the S\&P 500 index fell by 39 per cent between the same dates.

34 See Appendix B of the co-operation agreement, available in English at http://www.ppm.nu/ dbfiles/pdf/1573.pdf.

35 Association of British Insurers (2005) 'Serious about saving: serving individuals on lower incomes and working for SMEs. An Association of British Insurers' Paper for the Pensions Commission' ABI, London. 